\title{
バナナジュースはレボドパ製剤のバイオアベイラビリティを低下させる
}

\author{
小合由起, 砂金信義, ${ }^{*}$ 太田隆文, 宇留野 強
}

\section{Banana Juice Reduces Bioavailability of Levodopa Preparation}

\author{
Yuki Ogo, Nobuyoshi Sunagane, * Takafumi OHTA, and Tsutomu URUno \\ Faculty of Pharmaceutical Sciences, Tokyo University of Science (RIKADAI), \\ 2641 Yamazaki, Noda City 278-8510, Japan
}

(Received September 13, 2005; Accepted October 7, 2005)

\begin{abstract}
This study aimed to examine the effects of banana juice on levodopa bioavailability in rats. When a levodopa preparation (EC-Doparl tablets) was orally administered with banana juice made by mixing with a fresh banana and water, there were significant decreases in $C_{\max }(17.4 \pm 2.5 \mathrm{vs} .8 .6 \pm 3.1 \mu \mathrm{g} / \mathrm{ml} ; \alpha=0.05)$ and AUC $(1882.8 \pm 49.2 \mathrm{vs} .933 .5 \pm$ $286.6 \mu \mathrm{g} \cdot \mathrm{min} / \mathrm{ml} ; \alpha=0.05)$ for levodopa. On the other hand, administration of the levodopa preparation with a commercial beverage containing $10 \%$ banana juice resulted in no significant change in $C_{\max }$ or AUC. These results indicate that concomitant intake of levodopa preparations with banana juice, but not with a commercial banana beverage, may cause a drug-food interaction reducing levodopa bioavailability, and we should pay attention to such interactions during levodopa therapy for patients with Parkinson's disease.
\end{abstract}

Key words_-levodopa; banana juice; drug-food interaction

緒＼cjkstart言

グレープフルーツジュースやビタミン K 含有野 菜等の食品が医薬品と相互作用を発現し，医薬品の 体内動態に影響を及ぼすことが知られている．2005 年 7 月に製薬企業からインターネット Web 上に安 全性確保に関するお願いとして「レボドパ製剤とバ

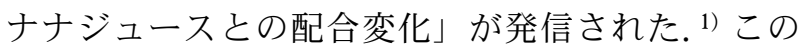
報告によるとレボドパ細粒製剤あるいは粉砕したレ ボドパ錠とバナナジュースを混合すると，溶液が変 色するとともにレボドパの含有量が時間とともに低 下し， 1 時間後には $50 \%$ 以下に低下する.レボドパ 製剤とバナナジュースを併用服用したときにこの反 応が進行すれば, レボドパの吸収量は減少し, バイ オアベイラビリティが低下することが予想される.

しかし，レボドパ製剤とバナナジュースの併用時に おけるレボドパの体内薬物動態についてはいまだ検 討されていない。そこで本研究では，バナナジュー ス及びバナナ成分含有清涼飲料水のレボドパの体内 動態に与える影響をラットを用いて検討した。

東京理科大学薬学部臨床薬学研究室

e-mail: sunagane@rs.noda.tus.ac.jp
方法

1. 使用薬物・食物レボドパ製剂（イー シー・ドパール錠, 協和発酵工業株式会社 ; レボ ドパ $100 \mathrm{mg}$ ，塩酸ベンセラジド $28.5 \mathrm{mg} / 1$ 錠）を 被験医薬品とした。バナナジュースは，企業が行つ た含量試験で採用した方法に準じてバナナ約 $5 \mathrm{~g}$ を すりおろし，水 $10 \mathrm{ml}$ を加えよく混合して作製し， バナナ成分含有清涼飲料水は，市販品（ラックミー 豆乳飲料（バナナ)，ヤクルト，バナナ果汁 $10 \%$ 未 満）を用いた。

2. 実験動物 8-9 週齢の Wistar 系雄性ラッ 卜（体重 220-270 g, 三協ラボサービス）を実験開 始の 24 時間前に絶食させて用いた。ラットは被験 医薬品の単独投与群と被験医薬品とバナナ及びバナ ナ含有清涼飲料水の混合投与群に無作為に分け, 各 群について 3 匹ずつ用いた。 ラットは, 採血のため にエーテル麻酔下に大腿動脈にカニューレ（ポリエ チレンチューブ， $\mathrm{sp} 31$ ，夏目製作所）をあらかじめ 挿入した。

\section{3. 薬物投与}

3-1.レボドパ製剤の投与量 レボドパ製剤の ラット投与量は，ヒトにおける成人 1 回服用量を標 
準体重（50 kg）で除した值をもとに，体重当たり の投与量に換算し，これを基準投与量とした。本研 究では HPLC による検出限界を考慮して基準投与 量の 25 倍量に相当する量（レボドパ原末量として $50 \mathrm{mg} / \mathrm{kg}$ ) を設定した.

3-2. 試料の調製 イーシー・ドパール錠を乳 鉢を用いて微粉化したものを，投与容量がラット体 重 $100 \mathrm{~g}$ 当たり $0.2 \mathrm{ml}$ となるように精製水に懸濁し て投与用試料とした。 バナナジュースあるいはバナ ナ成分含有飲料水を併用投与する場合は，粉砕した イーシー・ドパール錠をバナナジュース及びバナナ 成分含有清涼飲料水で懸濁して試料を調製した。

3-3. 投与法 カニューレ挿入手術の終了後お よそ90 分間経過し，麻酔から完全に覚醒したのち に，各懸濁試料をゾンデを用いて経口的に投与した.

\section{4. 採血及び測定試料の調製}

4-1. 採血ラットをボールマンケージに固定 したのちに，各測定時間毎に大腿動脈に挿入した力 ニューレを介してヘパリン処理シリンジを用いて 1 測定時当たり約 $0.4 \mathrm{ml}$ ずつ採血した。なお，採血 時以外はカニューレにはヘパリン溶液（200 単位/ $\mathrm{ml}$ ，ノボ・ヘパリン注，持田製薬）を注入してお き，採血に当たってはこのへパリン溶液を除去して から採血を行った.

4-2. 測定試料採取した血漿 $150 \mu \mathrm{l}$ に 0.5 $\mathrm{mol} / 1$ 過塩素酸液 $(450 \mu \mathrm{l})$ 加え，遠心分離 $(8000$ $\mathrm{g}, 10$ 分）して除タンパクし，上澄をさらに酢酸セ ルロースフィルター（Dismic-3, Advantec）でろ過 して，HPLC 測定試料とした.

5. HPLC 分析 レボドパの血中濃度の測定は Betto らの手法2)に準じた。 HPLC 分析には, HPLC 装置（LC-10ATVP，島津製作所）, ODS 力 ラム $(\mathrm{C} 18,4.6 \phi \times 150 \mathrm{~mm}, \mathrm{PEGASIL}$ ODS $)$ を用 いた．移動相にはオクタンスルホン酸ナトリウム $\left(\mathrm{OSA}, 2 \times 10^{-4} \mathrm{~mol} / \mathrm{l}\right)$ と EDTA $\cdot 2 \mathrm{Na}\left(3 \times 10^{-4}\right.$ $\mathrm{mol} / \mathrm{l})$ を含夕，酢酸で $\mathrm{pH} 3$ に調製した $0.025 \mathrm{~mol}$ /1 酶酸ナトリウム：メタノール（92：8）混合溶液 を用い, $0.9 \mathrm{ml} / \mathrm{min}$ で送液した。測定薬物の検出 は，分光光度計（FP-920，日本分光）を用い，励 起波長 $282 \mathrm{~nm}$, 蛍光波長 $322 \mathrm{~nm}$ の条件で行い, ピークデータ処理装置はクロマトパック C-R6A （島津製作所）を用いた。

6. 統計処理 各測定值は各群 3 例の平均值と
して求め, 平均值士標準誤差（S.E.）で示した。単 独投与群と併用群の平均值の差を Dunnett $の$ 多重 比較を用いて， $\alpha=0.05$ を有意水準として検定し た。なお，AUCは測定時間を底辺とする台形法を 用いて求めた。

結果

レボドパ製剂（イーシー・ドパール錠）を投与し たときのレボドパ血中濃度一時間曲線を Fig. 1 に 示した。レボドパ製剂単独投与時には，血中レボド パ濃度は投与 1 時間後に最大に達した後，徐々に低 下し，投与 4 時間後では $1.3 \mu \mathrm{g} / \mathrm{ml}$ となった。レボ ドパ製剤とバナナジュースを併用すると，レボドパ 血中濃度一時間曲線は下方へ大きく移動した。一 方，バナナ成分含有清涼飲料水を併用した際にも， レボドパ血中濃度一時間曲線は下方へ移動したが, バナナジュース併用時に比較して, 移動の程度は小 さかった.

レボドパの薬物動態パラメータを Table 1 に示し た。バナナジュースを併用すると，レボドパの最高 血漿中濃度 $\left(C_{\max }\right)$ は，単独投与時の $17.4 \pm 2.5 \mu \mathrm{g}$ $/ \mathrm{ml}$ から $8.6 \pm 3.1 \mu \mathrm{g} / \mathrm{ml}$ に有意に低下した。最高血 中濃度到達時間（ $\left.T_{\max }\right)$ は，バナナジュースの併用 により短縮する傾向を示したが有意な差は認められ なかった。また，レボドパの血中濃度一時間曲線下 面積（AUC）は，単独投与時の $1882.8 \pm 49.2 \mu \mathrm{g}$ ・ $\mathrm{min} / \mathrm{ml}$ からバナナジュースの併用により $933.5 \pm$ $286.6 \mu \mathrm{g} \cdot \mathrm{min} / \mathrm{ml}$ へと低下した。一方，バナナ成

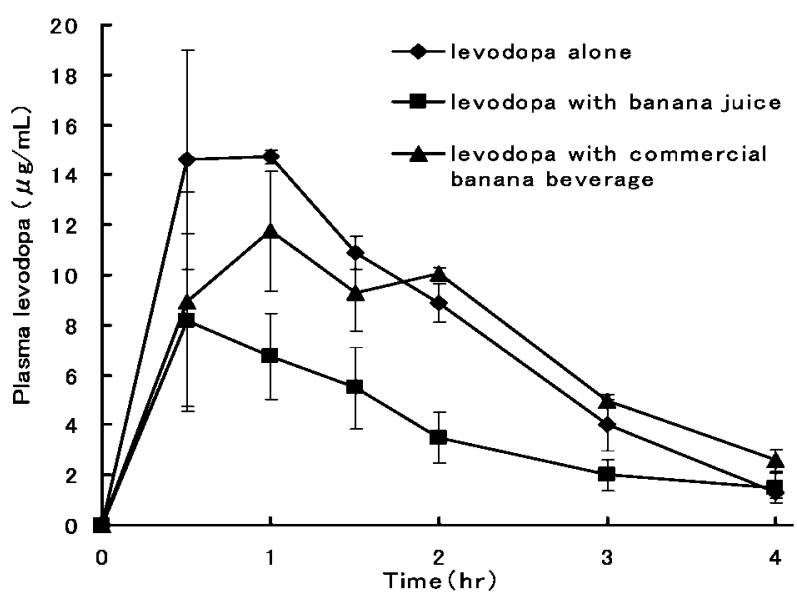

Fig. 1. Plasma Levodopa Concentration-time Curves in Rats Levodopa preparation (EC-DOPARL ${ }^{\circledR}$ Tablets) was administered without or with banana juice or commercial banana beverage. Data were expressed as mean \pm S.E. of 3 animals. 
Table 1. Pharmacokinetic Parameters for Levodopa in Rats

\begin{tabular}{lccc}
\hline \hline & $\begin{array}{c}\mathrm{AUC} C_{0} 240 \\
(\mu \mathrm{g} \cdot \mathrm{min} / \mathrm{ml})\end{array}$ & $\begin{array}{c}C_{\max } \\
(\mu \mathrm{g} / \mathrm{ml})\end{array}$ & $\begin{array}{c}T_{\max } \\
(\mathrm{min})\end{array}$ \\
\hline Levodopa alone & $1882.8 \pm 49.2$ & $17.4 \pm 2.5$ & $50 \pm 10$ \\
\hline $\begin{array}{l}\text { Levodopa with } \\
\text { banana juice }\end{array}$ & $933.5 \pm 286.6^{*}$ & $8.6 \pm 3.1^{*}$ & $40 \pm 10$ \\
\hline $\begin{array}{l}\text { Levodopa with } \\
\text { commercial } \\
\text { banana beverage }\end{array}$ & $1724.8 \pm 217.0$ & $12.7 \pm 1.8$ & $70 \pm 27$ \\
\hline
\end{tabular}

Data were represented as mean \pm S.E. $(n=3) .{ }^{*}: \alpha<0.05$ (Dunnett multiple comparison method).

分含有清涼飲料水を併用した際には，レボドパの $C_{\max }$ 及び AUC は低下する傾向を示したが，有意な 差は認められなかった。 また， $T_{\max }$ はバナナ成分 含有清涼飲料水併用によって延長する傾向を示した.

\section{考察}

本研究は，レボドパ製剤とバナナジュースを併用 投与すると，レボドパの AUCがレボドパ製剤単独 投与時の約 $50 \%$ までに低下し，レボドパのバイオ アベイラビリティが低下することを明らかにしてい る。この結果は，レボドパ製剤を服用する際にバナ ナジュースを併用すると, 医薬品一食物相互作用が 発現し，レボドパの血中濃度が低下して臨床効果が 減弱される可能性を示唆している.

企業から発信された安全性確保に関する情報「レ ボドパ製剤とバナナジュースとの配合変化」では, レボドパ製剤（イーシー・ドパール細粒） $45 \mathrm{mg}$ を 水 $150 \mathrm{ml}$ に溶解し，バナナジュース（バナナ $50 \mathrm{~g}$ と水 $100 \mathrm{ml}$ で作製）と配合したとき，溶液は赤色 に変色し，溶液中のレボドパ濃度は混合直後を 100 \%としたとき，配合の 30 分後では $56.2 \% ， 1$ 時間 後では $47.0 \%$ に低下すると報告している. ${ }^{1)}$ また, 錠剤（イーシー・ドパール錠）を粉砕して用いた場 合でも同様の結果が得られることも示されている.

報告では, この配合変化の原因についての詳細な説 明はないが，バナナに含まれるポリフェノールオキ シダーゼで触媒される酸化反応によりレボドパから メラニンを生成したためであろうと推測している. この反応は，果物の調理の過程で認められる褐変現 象の原因として知られている.

本研究で観察されたレボドパ製剤とバナナジュー スの併用による医薬品一食物相互作用は，レボドパ
製剂とバナナジュースとの配合変化のメカニズムで 同様に説明が可能である。経口投与された医薬品は 消化管を運ばれ，小腸に到達して吸収されるが，レ ボドパ製剤がバナナジュースと混合して投与される と，消化管の移動中に上に示したレボドパとバナナ 成分との反応が進行し，レボドパ含量が低下して, その結果消化管からのレボドパ吸収は低下し，レボ ドパの血中濃度一時間曲線は下方へ移動し， $C_{\max }$ も低下すると予想できる。この予想は本研究で得ら れた結果とよく一致している.

一方，バナナ成分含有飲料水の併用ではレボドパ の薬物動態パラメータの顕著な変化は観察されず, 医薬品一食品相互作用は検出されなかつた．本研究 で用いた飲料水は市販品であり, 内容物の変質を防 止するために殺菌，熱処理等が施されているものと 予想される。本飲料水はバナナ果汁を $10 \%$ 以下で 含有しているが，加熱処理等によりバナナ含有中の 褐変酵素が失活されているため, レボドパ製郕との 併用により相互作用が発現しなかったものと予想さ れる。また，含有するバナナ果汁が $10 \%$ と低いこ とも相互作用が認められなかったことに関係するか もしれない。しかし，バナナ成分含有飲料水の併用 によりレボドパの血中濃度一時間曲線の下方への移 動と， $C_{\max }$ の低下傾向を示しており，レボドパ製 剂を服用するに当たって市販バナナ成分含有飲料水 との併用には注意を払う必要があると考えられる。

結論として，レボドパ製剂を用いてパーキンソン 病患者の薬物療法を施行する際には，生バナナジ ユースで薬物一食物相互作用が発現し，その治療効 果が減退する可能性があることに留意する必要があ る.

謝辞 イーシー・ドパール錠を提供していただ きました協和発酵工業株式会社に感謝申し上げます。

\section{REFERENCES}

1) "Changes upon Mixing Levodopa Preparation $\left(\right.$ DOPARL $^{\circledR}$ ) and Banana Juice," Information about Safety Security for Drug Use $\langle$ http : //iyaku.kyowa.co.jp/〉, Kyowa Co., July-August, 2005.

2) Betto P., Ricciarello G., Giambenedetti M., Lucarelli C., J. Chromatogr., 459, 341-349 (1988). 